\title{
The importance of fluvial habitats for amphibian conservation in the Mediterranean climate
}

\author{
Wouter de Vries ${ }^{1}$, Adolfo Marco ${ }^{2, *}$ \\ ${ }^{1}$ Asociación Ambor, Carretera Constantina - El Pedroso km. 1, 41450 Constantina, Sevilla, Spain. \\ ${ }^{2}$ Doñana Biological Station, CSIC, C/Américo Vespucio s/n, 41092 Sevilla, Spain. \\ *Correspondence: Phone: +34 606252802, E-mail: amarco@ebd.csic.es
}

Received: 19 October 2016; returned for review: 21 December 2016; accepted 17 March 2017.

The importance of standing water habitat for amphibians is widely known and recognized. However, in some arid or semiarid zones the availability of these temporal habitats is uncertain and fluvial habitats could play a very important role for amphibian conservation. For example, in the Mediterranean region many fluvial habitats have a temporary character, lacking predatory fish populations and hosting diverse amphibian communities. To compare the relative importance of various fluvial and still water habitats, we studied the breeding amphibian community over a wide area from 2006 to 2008 in southwestern Spain. All amphibian species found in the area were present in lotic habitats and the highest amphibian diversity was found in temporary stream habitats. Fluvial habitats were among the most important habitats used for reproduction by eight amphibian species of conservation concern, whereas for seven species a significant positive selection was found towards one or several fluvial habitat types as reproduction habitats. The conservation of fluvial habitats including rigorous impact assessments and management programs can be very important for the conservation of endangered amphibians in these semi-arid areas.

Key words: amphibians; aquatic habitat; conservation; diversity; fluvial habitat; Mediterranean region.

Amphibians are declining worldwide and need urgent protection and restoration of their main habitats (BLAUSTEIN \& Kiesecker, 2002; Stuart et al., 2004; BLAustein \& Dobson, 2006). The right evaluation of the use of different aquatic habitats by amphibians is necessary for the design and implementation of conservation strategies for this highly threatened vertebrate group. Many field studies point out that ponds and pools are the most important amphibian habitats on temperate regions (GüNTHER, 1996; SeMlitsch \& Body, 1998; Snodgrass et al., 2000; Beja \& Alca-
ZAR, 2003) and might be essential for regional biodiversity (Semlitsch \& Bodie, 1998; Williams et al., 2004). In Europe, stream habitats are important for several amphibian species (e.g. Pleguezuelos et al., 2002; Creemers \& Van Delft, 2009) and also in other regions streams can be of high value for some species (e.g. Kroll et al., 2008; Welsh \& Hodgson, 2008; Grant et al., 2009). However, streams and rivers are usually unsuitable habitats for most amphibian species, mainly because of strong currents and high predation risk by fishes. Several studies in Britain have demon- 
strated the high value of pond habitats compared to rivers, streams and ditches (e.g. Biggs et al., 2000; Wood et al., 2003; Williams et al., 2004). In the Mediterranean region, temporary ponds are also valuable habitats for a wide range of freshwater fauna including amphibians (BoIx I MAsafret, 2002; Beja \& Alcazar, 2003; DíazPaniagua et al., 2005, 2006). However, in arid and semiarid zones of the Mediterranean region, temporary ponds can be scarce, strongly impacted by human activities and with a very short hydroperiod. In this scenario, streams and rivers that can also have a temporary character could play an important ecological role for the amphibian community. An exhaustive evaluation of the relative importance of fluvial habitats for amphibians is still lacking. Studies of aquatic communities within entire catchment areas are scarce and so far do not include amphibians (e.g. BIgGs et al., 2000; Williams et al., 2004). We investigated the entire amphibian community in a typical Mediterranean zone, surveying all amphibian species breeding in all types of available aquatic habitats, in order to obtain a comparative view of the relative importance of lentic and lotic habitats for the overall amphibian biodiversity as well as for endangered species.

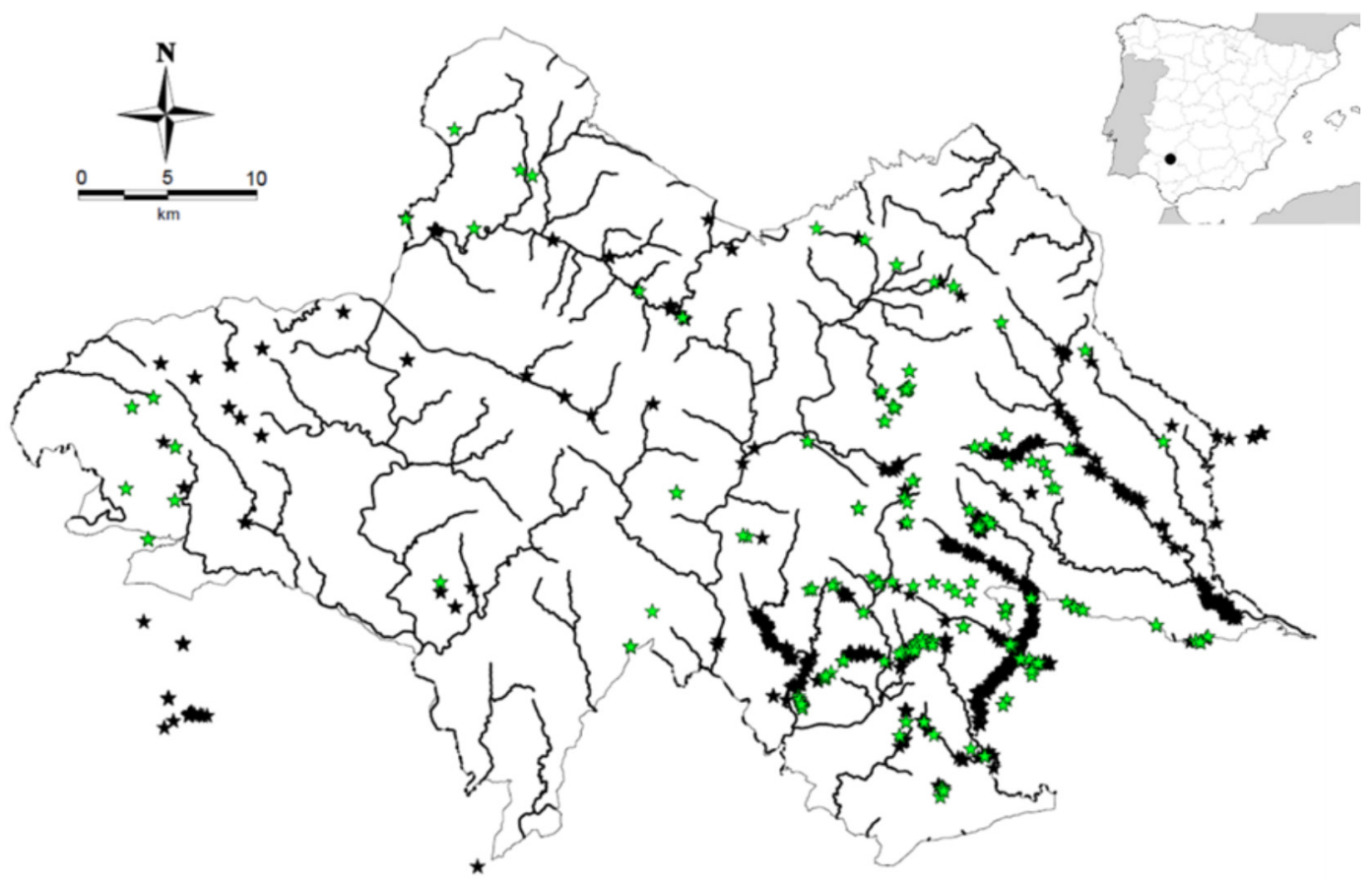

Figure 1: Map of the Sierra Norte de Sevilla Natural Park (southwestern Spain) and its location within the Iberian Peninsula, showing the main rivers and streams and all the waterbodies sampled for amphibians. Open stars correspond to lentic habitats and black stars correspond to lotic habitats. The vast majority of the sampled sites are inside the limits of the Natural Park and only few of them are in the external buffer zone. 


\section{Materials and Methods}

\section{Study sites}

To evaluate the relative importance of fluvial habitats on amphibian abundance and diversity we selected the Sierra Norte de Sevilla Natural Park (SNSNP, 177484 ha, Fig. 1) and adjacent non-protected surroundings. This area is located in the Sierra Morena range in the north of the province of Seville (southwestern Spain) and presents a high diversity and availability of freshwater ecosystems along with a significant amphibian diversity. The climate is typically Mediterranean with mean temperatures between 18.6 and $26.1^{\circ} \mathrm{C}$ in August and 4.3 to $13{ }^{\circ} \mathrm{C}$ in January, and an irregular precipitation of around $750 \mathrm{~mm}$ annually with maximum in winter (Consejería de Medio Ambiente, 2005). Previous studies have recorded the presence of at least 12 amphibian species (Pleguezuelos et al., 2002; De Vries et al., 2009). For a detailed description of the area, see Menor \& Cuenca (2008) and De VRIEs et al. (2009).

The 301 lotic aquatic habitats selected for the study (Fig. 1) were classified in three different categories: rivers, streams and ephemeral streams (Table 1). The rivers in the area are less than $10 \mathrm{~m}$ wide and seasonal, normally with running water in autumn, winter and spring, and lack of flowing water during the summer with

Table 1: Number of sampled sites (N), number of sites with amphibian presence (NA), number of amphibian breeding sites (NB) and number of sites sampled during the breeding period of each species, regardless of whether such species was detected or not. Ssal: Salamandra salamandra; Pwal: Pleurodeles waltl; Tpyg: Triturus pygmaeus; Lbos: Lissotriton boscai; Acis: Alytes cisternasii; Dgal: Discoglossus galganoi; Pibe: Pelodytes ibericus; Pcul: Pelobates cultripes; Bspi: Bufo spinosus; Ecal: Epidalea calamita; Hmer: Hyla meridionalis; Pper: Pelophylax perezi.

\begin{tabular}{|c|c|c|c|c|c|c|c|c|c|c|c|c|c|c|c|}
\hline $\begin{array}{c}\text { Habitat } \\
\text { type }\end{array}$ & $\mathbf{N}$ & NA & NB & Ssal & Pwal & Tpyg & Lbos & Acis & Dgal & Pibe & Pcul & Bspi & Ecal & Hmer & Pper \\
\hline River & 131 & 97 & 85 & 97 & 73 & 63 & 51 & 37 & 102 & 41 & 40 & 73 & 42 & 42 & 43 \\
\hline Stream & 137 & 112 & 101 & 112 & 104 & 72 & 101 & 66 & 137 & 61 & 78 & 102 & 59 & 72 & 59 \\
\hline $\begin{array}{l}\text { Ephemeral } \\
\text { stream }\end{array}$ & 33 & 29 & 23 & 29 & 21 & 21 & 26 & 21 & 21 & 17 & 15 & 21 & 21 & 26 & 21 \\
\hline Pond & 114 & 86 & 81 & 86 & 77 & 51 & 61 & 40 & 81 & 53 & 52 & 76 & 48 & 52 & 50 \\
\hline $\begin{array}{l}\text { Ephemeral } \\
\text { pond }\end{array}$ & 55 & 51 & 45 & 51 & 43 & 21 & 45 & 23 & 52 & 30 & 34 & 43 & 40 & 48 & 40 \\
\hline $\begin{array}{l}\text { Intact } \\
\text { cistern }\end{array}$ & 13 & 13 & 9 & 13 & 13 & 13 & 13 & 13 & 13 & 13 & 13 & 2 & 2 & 2 & 4 \\
\hline $\begin{array}{l}\text { Broken } \\
\text { cistern }\end{array}$ & 20 & 19 & 14 & 18 & 18 & 18 & 18 & 18 & 18 & 18 & 18 & 18 & 4 & 4 & 4 \\
\hline $\begin{array}{l}\text { Well \& } \\
\text { spring }\end{array}$ & 13 & 13 & 8 & 13 & 13 & 13 & 13 & 13 & 13 & 13 & 13 & 13 & 2 & 2 & 2 \\
\hline $\begin{array}{c}\text { Swimming } \\
\text { pool }\end{array}$ & 14 & 7 & 5 & 13 & 12 & 9 & 7 & 6 & 14 & 5 & 7 & 13 & 5 & 6 & 5 \\
\hline Trough & 10 & 6 & 4 & 7 & 5 & 5 & 5 & 3 & 6 & 4 & 3 & 5 & 2 & 4 & 6 \\
\hline
\end{tabular}


natural permanent pools remaining. These systems host a fish community of Cyprinidae and introduced exotic species (Prenda et al., 2006), and the introduced red swamp crayfish (Procambarus clarkii) as the most important large aquatic amphibian predators (e.g. Cruz \& Rebelo, 2005). Depending on the year and the amount of shadow, the rivers can support dense aquatic vegetation with Ranunculus sp. in late winter and spring. After strong rainfall, water levels can rise several meters for a few days. Depending on the meteorological and hydrological conditions, migrating fish go upstream for spawning or alternatively adults stay in the lower areas. With exception of short periods following heavy rainfall, streams have slow flowing water that usually forms series of interconnected ponds and pools during the amphibianbreeding period and dry out in summer, consequently lacking a permanent fish community. After heavy rainfall, aquatic vegetation is removed by the torrent. During the study years, we observed that ephemeral streams had running water for a few days or weeks, with small temporary pools $<1 \mathrm{~m}^{2}$ surface formed naturally by the water running along these streams.

The 239 lentic aquatic habitats selected (Fig. 1, Table 1) were classified in seven different categories: ponds (permanent or long-lasting temporary pools), ephemeral ponds (including flooded areas that can hold water for a few weeks to months), stone cisterns (either intact or broken, further on referred to as cistern), wells and springs, artificial swimming pools and troughs. The amount and diversity of aquatic vegetation in each site is highly variable and mainly depends on the live- stock density and occurrence period, and on cleaning frequency. Where livestock is absent (at least during part of the year) or has no access to the entire pond area, there is usually vegetation of the genera Callitriche, Potamogeton and sometimes Chara, Typha and Juncus.

\section{Data collection and analysis}

Data on amphibians were recorded during three consecutive years (2006-08) using standard methods for amphibian surveys (Heyer et al., 1994; Glandt, 2011). Sampling included calling surveys, surveys on land near the water bodies, visual survey in or at the water, net sampling in water and terrestrial surveys near the waterbodies for metamorphs. Precipitation during the study years was normal, with 2006 being slightly wetter and 2007 and 2008 drier years, with annual rainfall of 659.4354 .3 and $505.2 \mathrm{~mm}$, respectively, at San Pablo airport, 60 kilometres from the study area (average \pm SD of annual precipitation data in the period 1973-2008 $=543.3$ $\pm 201.0 \mathrm{~mm}$ ).

For each amphibian species, only data from the sites that were sampled with appropriate conditions to detect these species (suitable observation method, as well as appropriate time of the year, sampling technique and weather and hydrological conditions at the site during samplings) were used in the analysis. Due to important phenological differences in the reproduction of different species, the field surveys were distributed throughout the autumn, winter and early spring of every study year. The studied localities were widely distributed over the natural park area (Fig. 1) including three main basins 
(the river Huéznar in the centre of the Park, the river Viar in the west part and the river Retortillo in the east part) and many secondary basins. Study sites were defined as isolated water bodies or stretches of 500 meters of length along a permanent or temporary running water habitat. Data on ephemeral streams, streams and rivers were grouped per stretch of 500 meters using the software ArcView 3.2 (ESRI, Redlands, California, USA), resulting in approximately 500 to $1000 \mathrm{~m}^{2}$ of surface area per site.

For each site, the species, number of individuals at each developmental stage, type of aquatic habitat and geographic coordinates (GPS eTrex®, Garmin, Olathe, Kansas, USA) were registered. Eleven amphibian species had been widely found throughout the area in previous studies (De Vries et al., 2009). Moreover, the Iberian parsley frog (Pelodytes ibericus) is considered rare and with a discontinuous distribution. The European treefrog (Hyla molleri) has been sporadically described for the area (Pleguezuelos et al., 2002; Reques et al., 2006). We registered for each species, year and type of habitat the number of breeding localities considering only the presence of eggs, larvae or metamorphs.

All statistical analyses were calculated using the presence or absence of each species on each sampled site. We calculated the percentage of locations of each habitat type with the presence of each amphibian species. We proceeded similarly for each species considering together all the lentic or lotic habitats. In order to evaluate the relative importance of each type of habitat for each amphibian species, chi-square tests (STATISTICA, Statsoft Inc., Tusla,
Oklahoma, USA) were performed for each amphibian species comparing the observed frequencies of sites of each habitat with successful breeding with the expected frequency if the selection were random. For each chi-square analysis, the habitat categories where the expected frequency was lower than 5 were excluded from this analysis. Similar chi-square analyses were conducted pooling all data from either lentic of lotic habitats together. The Bonferroni correction for multiple comparisons was applied. We calculated the diversity of breeding amphibians on each type of habitat using the Shannon index (Krebs, 1989). For this calculation, the abundance of each species on each type of habitat was considered as the percentage of sites of each habitat with evidence of breeding activity of the selected species in any of the three study years.

Considering the results of the chisquare tests to evaluate the relative importance of each type of habitat, four categories were defined to indicate the value of fluvial habitats for each amphibian species in the study area: 0: no statistically significant selection of fluvial habitats and $<25 \%$ of breeding sites corresponding to fluvial habitats; 1 : $>25 \%$ of breeding sites corresponding to fluvial habitats but no statistically significant selection of any fluvial habitat type; 2 : statistically significant $(P<0.05)$ selection of any of the three fluvial habitat types; and 3: highly significant $(P<$ 0.001 ) selection of any of the three fluvial habitat types.

\section{Results}

Reproduction of amphibians was detected in 375 out of 540 sampled sites 
斊 흥 它 ट

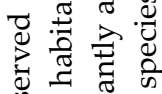
ه च के

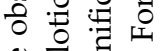

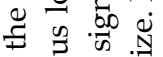
bo

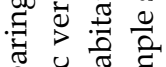

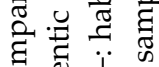
8웡

의 政要 (ृ) 들

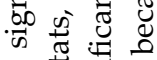
㱐 (5) एटं

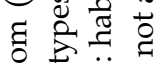

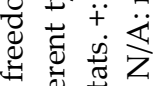

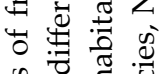

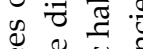

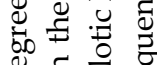
政: 은 bo. 잉

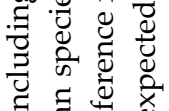
द) S) 旅 을 区ै o to

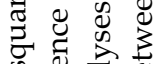
它 들 형

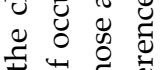

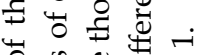

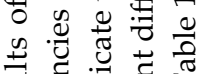

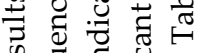
约 ن

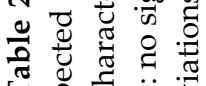

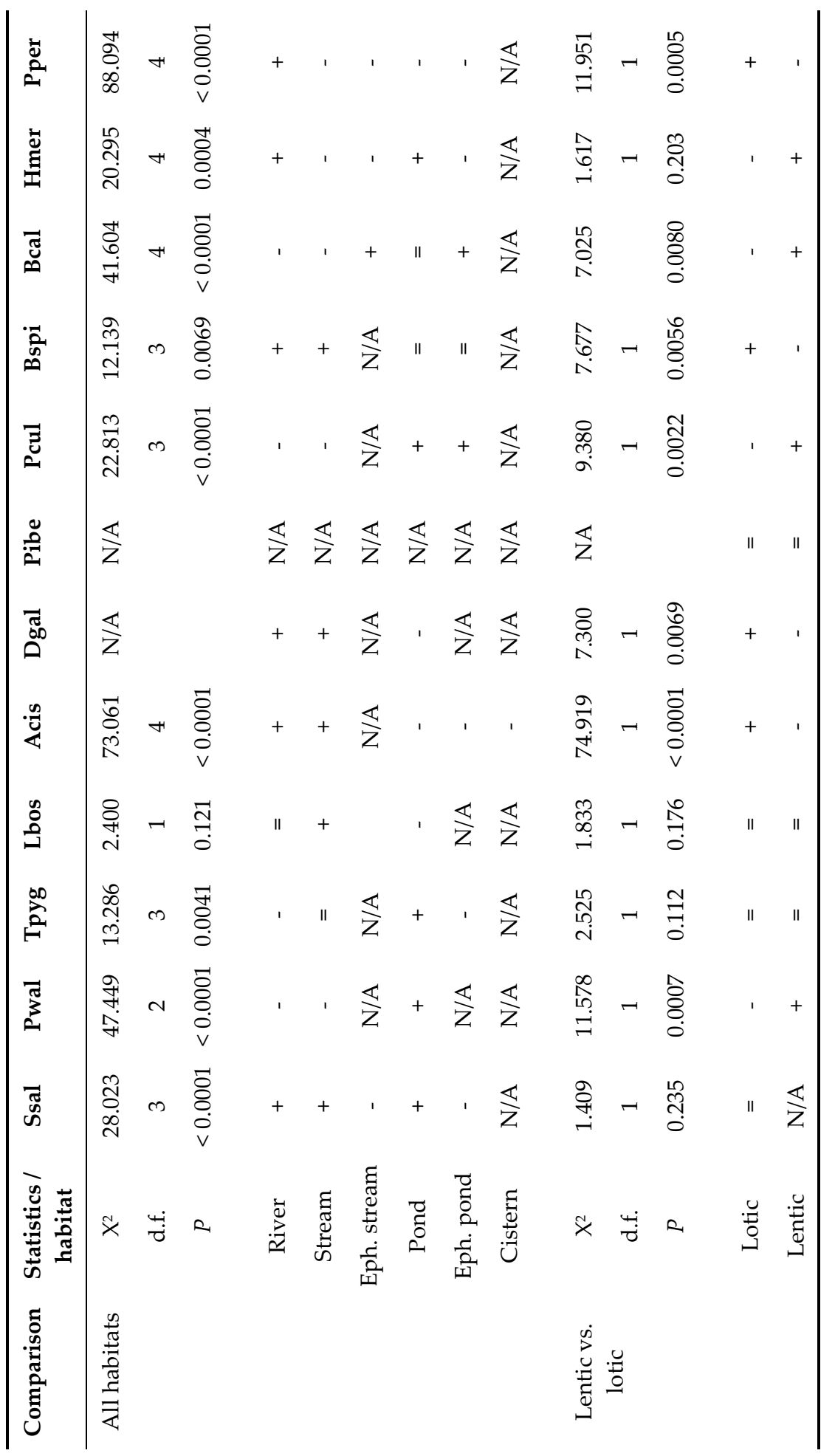


(Table 1). The community of amphibians breeding at each site as well as species diversity varied according to the habitat type (Table 2). The 12 species present in the area were recorded breeding in both fluvial and still water habitats. Ten species had more than $25 \%$ of their observations in lotic habitats and six species were more common in fluvial than in stagnant water ecosystems. Lotic habitats were especially important for the Iberian midwife toad (Alytes cisternasii), the Iberian painted frog (Discoglossus galganoi) and the green frog (Pelophylax perezi) (Fig. 2).

Fluvial habitats were significantly preferred for breeding by five species: the common salamander (Salamandra salamandra), A. cisternassi, D. galganoi, the com- mon toad (Bufo spinosus) and P. perezi, and significantly avoided by four species: the sharp-ribbed salamander (Pleurodeles waltl), the pygmy newt (Triturus pygmaeus), the spadefoot toad (Pelobates cultripes) and the natterjack toad (Epidalea calamita), which preferred in lentic habitats (Table 2). The chi-square test also showed significant differences on habitat selection by the southern treefrog (Hyla meridionalis) but there was no differences in selection between lentic and lotic habitats (Table 2). Pelodytes ibericus was rare and the sample size did not permit a chi-square analysis, although its frequency in each type of habitat suggests that it prefers lentic habitats (Table 2). The only species for which no significant preference for any habitat type

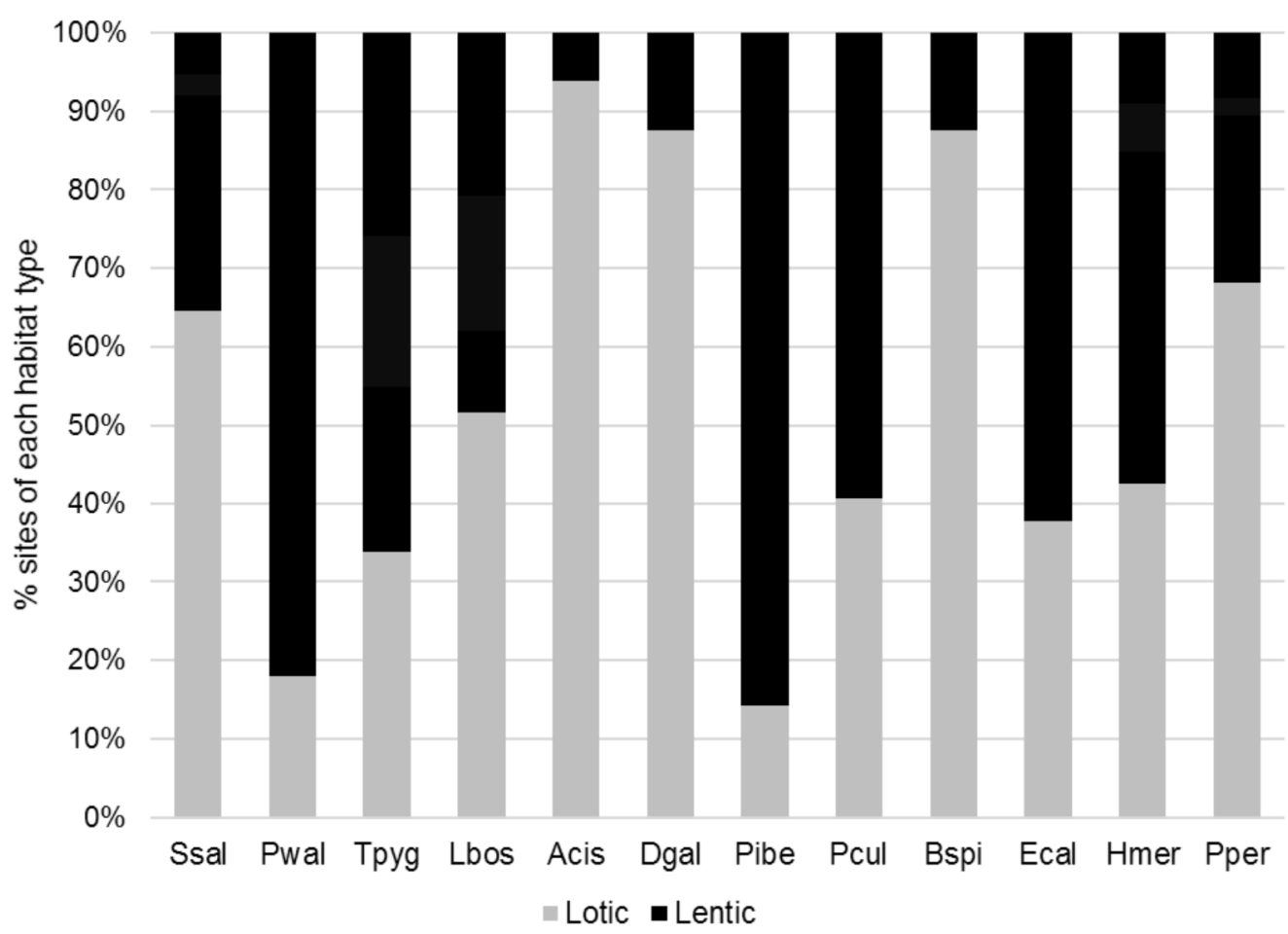

Figure 2: Percentage of breeding sites of each amphibian species corresponding to lotic and lentic habitats. For species abbreviations, see Table 1. 
was recorded was the Iberian newt (Lissotriton boscai) (Table 2). Fluvial habitats were of high importance for one vulnerable and six nearly threatened species (Table 3).

The amphibian diversity was especially high in all fluvial habitats and in the ponds, whereas lower species diversity values were found for smaller or artificial ecosystems (Fig. 3). Temporary streams had the highest diversity index followed by ponds.

\section{Discussion}

In the Mediterranean region, the high species diversity and abundance of amphibians might be explained by their abil- ity to use fluvial as well as still water habitats, allowing survival of populations during successive years with low water tables and absence of ponds, even of temporary ones. Fortuna et al. (2006) suggested that a network of a large number of different types of temporary aquatic habitats is a key factor for a favourable conservation status of amphibian populations, and BEJA \& Alcazar (2003) showed that conservation of amphibian assemblages in temporary ponds on Mediterranean farmlands requires networks of ponds with diverse hydroperiods. Our results indicate that temporary fluvial habitats in the Mediterranean region are also important in this respect, which is in accordance with the

Table 3: Importance of lotic habitats in the SNSNP for amphibians according to their legal protection in Spain and the European Union (EU) and to their conservation status at European, national (i.e. Spain) and regional (i.e. Andalusia) levels. For explanation of the fluvial habitat importance categories, see Materials and Methods. For species abbreviations, see Table 1. SP: species with Special Protection level in Spain according to the Spanish legislation (Real Decreto 139/2011, de 4 de febrero 2011), IV: species of community interest that require strict protection according to Habitat Directive of the European Union (Directive 92/43/EEC). c As Triturus marmoratus. d,e,f LC: of Least Concern, NT: Near Threatened, VU: Vulnerable, DD: Data Deficient.

\begin{tabular}{|c|c|c|c|c|c|c|}
\hline \multirow[t]{2}{*}{ Species } & \multirow{2}{*}{$\begin{array}{l}\text { Importance of } \\
\text { lotic habitats }\end{array}$} & \multicolumn{2}{|c|}{ Legal protection } & \multicolumn{3}{|c|}{ Conservation status } \\
\hline & & Spain & EU & European $^{1}$ & National $^{3}$ & Regional $^{4}$ \\
\hline Pwal & 0 & SP & & NT & NT & NT \\
\hline Ssal & 2 & & & & NT & $\mathrm{NT}^{5}$ \\
\hline Lbos & 2 & SP & & & NT & NT \\
\hline Tpyg & 1 & SP & IV & $\mathrm{NT}^{2}$ & VU & $\mathrm{VU}^{6}$ \\
\hline Acis & 3 & SP & IV & NT & NT & NT \\
\hline Dgal & 2 & SP & IV & & & \\
\hline Pcul & 1 & SP & IV & NT & NT & NT \\
\hline Pibe & 0 & SP & & & DD & NT \\
\hline Bspi & 2 & & & & & \\
\hline Bcal & 2 & SP & IV & & & \\
\hline Hmer & 1 & SP & IV & & NT & NT \\
\hline Pper & 3 & & & & & \\
\hline
\end{tabular}

${ }^{1}$ According to Temple \& Cox (2009); ${ }^{2}$ according to Arntzen et al. (2009); 3according to Pleguezuelos et al. (2002); ${ }^{4}$ according to Franco Ruiz \& Rodríguez de los Santos (2001) and Reques et al. (2006); 5as Salamandra salamand ra morenica; ${ }^{6}$ eastern populations, as Triturus marmoratus pygmaeus. 


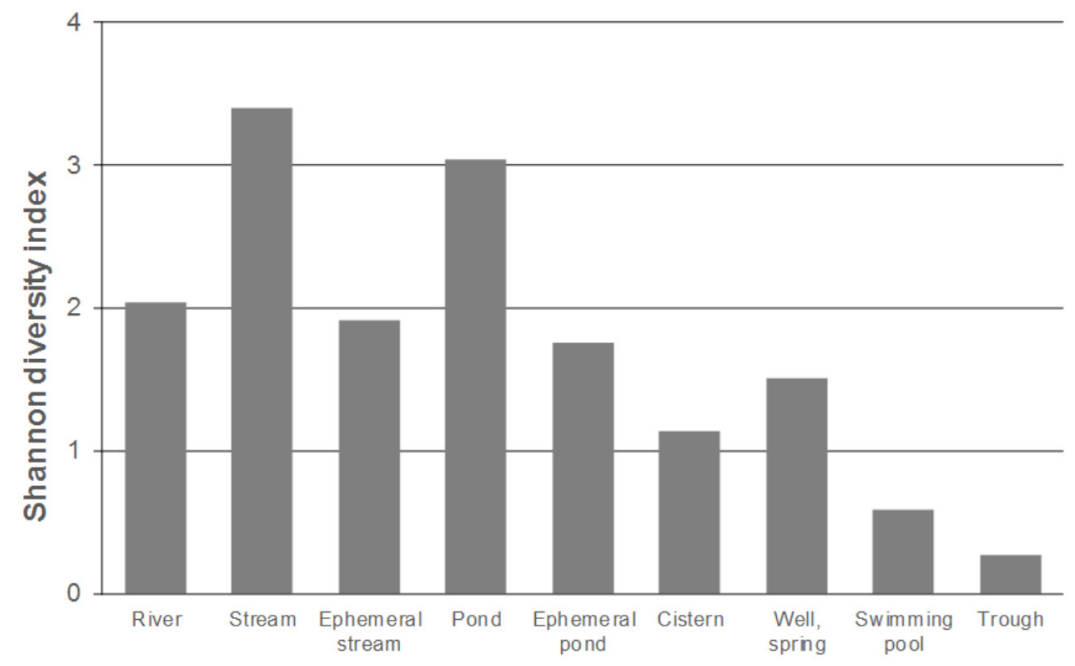

Figure 3: Shannon index of amphibian species diversity in each type of aquatic habitat.

findings of Wood et al. (2003), who stressed the necessity of preserving temporary aquatic habitats for the conservation of amphibians. Fluvial habitats regularly form a part of such networks of temporary waterbodies in the Mediterranean region.

Various studies indicate a positive correlation between hydroperiod and amphibian diversity (e.g. SNOdgrass et al., 2000; Beja \& Alcazar, 2003; DíazPaniagua et al., 2006). In these studies, as well as in the present ones, it is observed that the long-lasting, but not permanent, waterbodies were the most valuable for the amphibians. Our study shows also the additional value that fluvial habitats with long but not permanent hydroperiods have, indicating that for the conservation of amphibian communities within ecosystems, measures should be directed at both still water and fluvial temporary habitats.

Beja \& Alcazar (2003) observed amphibians in 53 out of 57 ponds (ephemeral, temporal and permanent) in a lowland area in a Natural Park in southwestern Portugal. Species occurring in both their and our study areas had similar site occupancy, though for most species it was lower at SNSNP. Both studies indicate a high value of ponds as amphibian habitat, but at the same time several species in SNSNP had similar or even higher site occupancy in fluvial habitats. Díaz-Paniagua et al. (2006) demonstrated a high importance of temporary and permanent ponds and lakes in Doñana in southwestern Spain. Seven amphibian species were recorded breeding in the few fluvial habitats studied there, with averages of 3.9 species per site for slow-flowing waters and 1.5 species per site for fast-flowing streams. Our data are in accordance with those of DíazPaniagua (1990) and Díaz-Paniagua et al. (2006), who observed a high importance of especially long-lasting temporary habitats for most species, and also of ephemeral habitats for E. calamita and fluvial habitats for $A$. cisternasi. We observed a remarkably low occurrence and importance of ephemeral ponds for D. galganoi compared to the aforementioned studies conducted in Doñana; the ephemeral micro- 
habitat used by this species during the present study consisted mainly of inundations along streams banks.

Fluvial ecosystems in the Mediterranean climate are considered suitable aquatic habitats for all the species found in this study except E. calamita in southwestern Europe (e.g. Barbadillo et al., 1999; ReQues, 2000; Salvador 2009). In the present study, we have quantified the high importance of such fluvial habitats for amphibian communities in a typical Mediterranean ecosystem in years with normal precipitation. The inter-annual variations in hydroperiod contribute to the long-term conservation of the amphibian community by enhancing habitat for different species in different years (ЈАков et al., 2003). At the species level, our data indicate that fluvial habitats in the Mediterranean region are of high importance for one Vulnerable and six Nearly Threatened species (Table 3). For seven out of nine species of conservation concern (i.e. T. pygmaeus, L. boscai, A. cisternasii, D. galganoi, P. cultripes, $E$. calamita and $H$. meridionalis), which require special protection according to the Spanish legislation (Real Decreto 139/2011, de 4 de febrero 2011) fluvial habitat is important or even the preferred habitat. For six species of European Community Interest (Annex IV of the European Habitats Directive 92/43/EEC), fluvial habitat is among their important habitats in our study area, being the most important one for $A$. cisternasii and D. galganoi. For A cisternasii, a globally Nearly Threatened Iberian endemism, the fluvial habitats were of highest, almost unique importance in the SNSNP, as in other Mediterranean ecosystems (BEJA et al., 2009). Thus, our study indicates the high conservation value that Mediterranean fluvial habitats have for amphibians. Mediterranean temporary lotic ecosystems should be considered for listing on the European Habitat Directive because of their high importance to amphibians.

\section{Acknowledgement}

This study was possible thanks to the good cooperation with the Natural Park Sierra Norte de Sevilla (Consejería de Medio Ambiente) and landowners in the area. We especially appreciate the support from the Directora Conservadora I. Cuenca and other members of the Natural Parks' staff (A. Menor, L.M. Platero) for facilitating authorizations and stimulating studies on herpetology within the Park. Furthermore, we had great help and information on valuable areas or literature on amphibians from J. Llorente, F. Ugía, A. García, M.C. Perez, P. Carmona (ACPES), N. Selva and J. Kielgast. We are thankful to Jim Foster for improving the language in the English manuscript.

\section{REFERENCES}

Arntzen, J.W.; Jehle, R.; Bosch, J.; Miaud, C.; Tejedo, M.; Lizana, M.; Martínez-Solano, I.; Salvador, A.; García-París, M.; Recuero Gil, E.; SÁ-Sousa, P. \& Márquez R. (2009). Triturus marmoratus. The IUCN Red List of Threatened Species 2009: e.T59477A11949129.

Barbadillo. L.J.; Lacomba, J.I.; Pérez-Mellado, V.; Sancho, V. \& López-Jurado, L.F. (1999). Anfibios y Reptiles de la Península Ibérica, Baleares y Canarias. GeoPlaneta, Barcelona, Spain.

Blaustein, A.R. \& Dobson, A. (2006). Extinctions: A message from the frogs. Nature 439: 143-144.

Blaustein, A.R. \& Kiesecker, J.M. (2002). Complexity in conservation: lessons from the 
global decline of amphibian populations. Ecology Letters 5: 597-608.

Beja, P., \& Alcazar, R. (2003). Conservation of Mediterranean temporary ponds under agricultural intensification: an evaluation using amphibians. Biological Conservation 114: 317-326.

Beja, P.; Bosch, J.; Tejedo, M.; Lizana, M.; Martínez-Solano, I.; Salvador, A.; GarcíaParís, M.; Recuero Gil, E.; Arntzen, J.W.; Marquez, R. \& Díaz-Paniagua, C. (2009). Alytes cisternasii. The IUCN Red List of Threatened Species 2009: e.T55266A11283060.

Biggs, J.; Whitfield, M.; Williams, P.; Fox, G. \& Nicolet, P. (2000). Factors affecting the nature conservation value of ponds: results of the National Pond Survey, In Proceedings of the Ponds Conference 1998. Pond Action, Oxford, UK.

Boix i Masafret, D. (2002). Aportació al coneixement de la distribució dánostracis i notostracis (Crustacea: Branchiopoda) als Països Catalans. Butlletí de la Institució Catalana d'Història Natural 70: 55-71.

Consejería de Medio Ambiente (2005). Parque Natural Sierra Norte de Sevilla. Plan de Ordenación de los Recursos Naturales / Plan Rector de Uso y Gestión / Plan de Desarrollo Sostenible. Junta de Andalucía, Sevilla, Spain.

Creemers, R.C.M. \& van Delft, J.J.C.W. (2009). De amfibiëen en reptielen van Nederland. Series: Nederlandse Fauna, vol. 9. Nationaal Natuurhisorisch Museum Naturalis, European Invertebrate Survey, Leiden, The Netherlands.

Cruz, M.J. \& Rebelo, R. (2005). Vulnerability of southwest Iberian amphibians to an introduced crayfish, Procamburus clarkii. Amphibia-Reptilia 26: 293-303.

De Vries, W.; Marco, A. \& Menor, A. (2009). Distribución y diversidad de anfibios en la Sierra Norte de Sevilla. Boletín de la Asociación Herpetológica Española 20: 74-79.

Díaz-Paniagua, C. (1990). Temporal segregation in larval amphibian communities in temporary ponds at a locality in SW Spain.
Amphibia-Reptilia 9: 15-26.

Díaz-Paniagua， C.; Gómez-Rodríguez， C.; Portheault, A. \& De Vries, W. (2005). Los Anfibios de Doñana. Organismo Autónomo Parques Nacionales, Ministerio de Medio Ambiente, Madrid, Spain.

Díaz-Paniagua, C.; Gómez-Rodríguez, C.; Portheault, A. \& De Vries, W. (2006). Distribución de los anfibios del Parque Nacional de Doñana en función de la densidad y abundancia de los hábitats de reproducción. Revista Española de Herpetología 20: 17-30.

Fortuna, M.A.; Gómez-Rodríguez, C. \& BasсомРтE, J. (2006). Spatial network structure and amphibians persistence in stochastic environments. Proceedings of the Royal Society B 273: 1429-1434.

Franco Ruiz, A. \& Rodríguez de los Santos, M. (2001). Libro Rojo de los Vertebrados Amenazados de Andalucía. Consejería de Medio Ambiente, Junta de Andalucía, Sevilla, Spain.

Glandt, D. (2011). Grundkurs Amphibien- und Reptilienbestimung. Beobachten, Erfassen und Bestimmen aller europäischen Arten. Quelle \& Meyer Verlag $\mathrm{GmbH} \&$ Co., Wiebelsheim, Germany.

Grant, E.H.C.; Green L.E. \& Lowe, W.H. (2009). Salamander occupancy in headwater stream networks. Freshwater Biology 54: 1370-1378.

Günther, R. (1996). Die Amphibien und Reptilien Deutschlands. Gustav Fischer Verlag, Jena, Germany.

Heyer, R.W.; Donelly, M.A.; McDiarmid, R.W.; HayeK, L.A. \& Foster, M.S. (1994). Measuring and Monitoring Biological Diversity. Standard Methods for Amphibians. Smithsonian Institution, Washington, DC, USA.

Jаков, C.; Poizat, G.; Veith, M.; Seitz, A. \& Crivelli, A.J. (2003). Breeding phenology and larval distribution of amphibians in a Mediterranean pond network with unpredictable hydrology. Hydrobiologia 499: 5161.

Krebs, C. (1989). Ecological Methodology. Happer Collins, New York, USA.

Kroll, A.J.; Risenhoover, K.; McBride, T.; 
Beach, E.; Kernohan, B.J.; Light, J. \& Bach, J. (2008). Factors influencing stream occupancy and detection probability parameters of stream-associated amphibians in commercial forests of Oregon and Washington, USA. Forest Ecology and Management 255: 3726-3735.

Menor, A. \& Cuenca, I. (2008). Investigación Científica y Conservación en el Parque Natural Sierra Norte de Sevilla. Consejería de Medio Ambiente, Junta de Andalucía, Sevilla, Spain.

Pleguezuelos, J.M.; Márquez, R. \& Lizana, M. (2002). Atlas y Libro Rojo de los Anfibios y Reptiles de España. Dirección General de Conservación de la Naturaleza - Asociación Herpetológica Española, Madrid, Spain.

Prenda, J.; Clavero, M.; Blanco-Garrido, F.; Menor, A. \& Hermoso, V. (2006). Threats to the conservation of biotic integrity in Iberian fluvial ecosystems. Limnetica 25: $377-$ 388.

Reques, R. (2000). Anfibios. Ecología y Conservación. Series: Recursos Naturales de Córdoba. Diputación de Córdoba, Delegación de Medio Ambiente y Protección Civil, Córdoba, Spain.

Reques, R.; Caro-Hidalgo, J. \& Pleguezuelos, J.M. (2006). Parajes Importantes para la Conservación de Anfibios y Reptiles en España. Consejería de Medio Ambiente, Junta de Andalucía, Sevilla, Spain.

Salvador, A. (2009). Enciclopedia Virtual de los Vertebrados Españoles. Museo Nacional de Ciencias Naturales CSIC, Madrid, Spain.
Available

at http:// www.vertebradosibericos.org. Retrieved on 12 September 2016.

Semlitsch, R.D. \& Bodie, J.R. (1998). Are small, isolated wetlands expendable? Conservation Biology 12: 1129-1133.

Snodgrass, J.W.; Komoroski, M.J.; Bryan, A.L., JR. \& BURger, J. (2000). Relationships among isolated wetland size, hydroperiod, and amphibian species richness: implications for wetland regulations. Conservation Biology 14: 414-419.

Stuart, S.N.; Chanson, J.S.; Cox, N.A.; Young, B.E.; Rodrigues, A.S.L.; Fischman, D.L. \& WALLER, R.W. (2004). Status and trends of amphibian declines and extinctions worldwide. Science 306: 1783-1786.

Temple, H.J. \& Cox, N.A. (2009). European Red List of Amphibians. Office for Official Publications of the European Commission, Luxembourg.

Welsh, H.H. \& Hodgson, G.R. (2008). Amphibians as metrics of critical biological thresholds in forested headwater streams of the Pacific Northwest, U.S.A. Freshwater Biology 53: 1470-1488.

Williams, P.; Whitfield, M.; Biggs, J.; Bray, S.; Fox, G.; Nicolet, P. \& Sear, D. (2004). Comparative biodiversity of rivers, streams, ditches and ponds in an agricultural landscape in Southern England. Biological Conservation 115: 329-341.

Wood, P.J.; Greenwood, M.T. \& Agnew, M.D. (2003). Pond biodiversity and habitat loss in the UK. Area 35: 206-216. 